Article

\title{
Multiculturalism, Gender and Bend it Like Beckham
}

\author{
Gamal Abdel-Shehid ${ }^{1}$ and Nathan Kalman-Lamb ${ }^{2, *}$ \\ ${ }^{1}$ School of Kinesiology and Health Sciences, York University, Toronto, ON, M3J 1P3, Canada; E-Mail: gamal@yorku.ca \\ ${ }^{2}$ Graduate Programme in Social and Political Thought, York University, Toronto, ON, M3J 1P3, Canada; \\ E-Mail: lambnath@yorku.ca \\ * Corresponding author
}

Submitted: 14 July 2014 | In Revised Form: 2 October 2014 | Accepted: 10 November 2014 |

Published: 25 June 2015

\begin{abstract}
In this article, we explore the efficacy of sport as an instrument for social inclusion through an analysis of the film Bend it Like Beckham. The film argues for the potential of sport to foster a more inclusive society in terms of multiculturalism and gender equity by showing how a hybrid culture can be forged through the microcosm of an English young women's football club, while simultaneously challenging assumptions about traditional masculinities and femininities. Yet, despite appearances, Bend it Like Beckham does little to challenge the structure of English society. Ultimately, the version of multiculturalism offered by the film is one of assimilation to a utopian English norm. This conception appears progressive in its availability to all Britons regardless of ethnicity, but falls short of conceptions of hybrid identity that do not privilege one hegemonic culture over others. Likewise, although the film presents a feminist veneer, underneath lurks a troubling reassertion of the value of chastity, masculinity, and patriarchy. Bend it Like Beckham thus provides an instructive case study for the potential of sport as a site of social inclusion because it reveals how seductive it is to imagine that structural inequalities can be overcome through involvement in teams.
\end{abstract}

\section{Keywords}

film; gender; multiculturalism; sport

Issue

This article is part of the special issue "Sport for Social Inclusion: Critical Analyses and Future Challenges", edited by Dr. Reinhard Haudenhuyse (Vrije Universiteit Brussel, Belgium) and Professor Marc Theeboom (Vrije Universiteit Brussel, Belgium).

(C) 2015 by the authors; licensee Cogitatio (Lisbon, Portugal). This article is licensed under a Creative Commons Attribution 4.0 International License (CC BY).

\section{Introduction}

The 2002 film Bend it Like Beckham offers perhaps the most sophisticated and nuanced narrative of sport, race, and gender of any recent mainstream picture. This makes the film particularly seductive from an ideological standpoint, for it invites us to share in its vision for a better society. Precisely for this reason, it is incumbent upon more critical viewers of the film to interrogate exactly what lessons the film propagates to its audience, for the film asks important questions about multiculturalism, gender, and sport that must be taken very seriously. Foremost among them is the question of what multiculturalism and gender equity actually look like. The film offers us a vision and it is important to ask whether that vision is one we should collectively aspire to.

In what follows, using a cultural studies approach, we argue that the film ultimately provides an overly triumphalist version of contemporary multicultural society. We do this by examining a variety of the film's underlying assumptions. First, we suggest that like most sports films, Bend it Like Beckham operates through the category of "transcendence", framing sport as an arena of opportunity in which structural inequities like racism and patriarchy can be overcome 
through hard work and athletic excellence. Second, we argue that the film reinforces the "culture clash" understanding of society, an approach that blames nonhegemonic groups for causing any friction within the liberal society on account of their refusal to fully integrate to the principles and norms of the liberal (white, masculine, heterosexual) state, thereby reasserting the centrality of whiteness and normative femininity, which includes heterosexuality. Third, and relatedly, we contend that the film in part accomplishes this "culture clash" project by completely dismissing traditional Indian femininity. Finally, we argue for an alternative vision of cultural openness as a more productive way to discuss multiculturalism.

\section{Context and Rationale}

Before examining the film itself, it is worth addressing why we have chosen to write at length about a film from 2002 that is set in a different country from the one in which we currently reside (Canada). We see Bend it Like Beckham as having significant value within a discussion of sport and social inclusion for the following reasons. The film, while set in England, serves as a useful discussion point for social inclusion in both the British context and for ex-British settler colonies/nations, such as Canada, due to the somewhat homologous ways in which multiculturalism, official and otherwise, applies in both contexts. Although distinct in the particularities of their histories, nations such as Britain, Canada, and Australia, among others, share a legacy of whiteness, Englishness, and masculinity that has been forced to confront the reality of postcolonial migration from non-white populations across the globe. In each of these countries, the policy of multiculturalism (rather than straight assimilation) has been adopted as a mechanism designed to produce social cohesion (and, we argue, to ultimately preserve the legitimacy of white, masculine hegemony). Second, the film, although over ten years old, still applies to the current context, given the tenacious persistence of racial and gender inequality within Canada and Britain respectively. Third, the film had and still has a significant popular appeal. In fact, as has been noted by Sara Ahmed (2010) it is one of the largest grossing all-British films of all time and received widespread play in places like Canada as well as Britain itself, in the process informing ideas about multiculturalism across the English-speaking world.

Our approach in this paper builds on other treatments of the film, such as those of Michael Giardina (2006) and Sara Ahmed (2010). Both Giardina and Ahmed make similar arguments to our own, by which we mean that they point out the limitations of the film from the point of view of recent trends in cultural studies and critical race theory. Giardina's (2006) main contribution is to point out that the film offers the viewer a vision of "stylish hybridity" - a celebratory version of multiculturalism that ignores the persistent realities of racism within contemporary England. Ahmed (2010) makes a similar claim, although she reads the film within the larger discussion of "happiness" and suggests that the film is based on overlooking structural inequalities in order to offer individual happiness as the way out of racial inequality. Both authors index in their own ways the ultimately neo-liberal orientation of the film, one that celebrates the agency of the individual while paying scant attention to the structural impediments racialized people face in liberal multicultural societies.

This article contributes to and extends the scholarship around Bend it like Beckkham in three primary ways. First, we situate the film in the broader context of mainstream film about sport. Second, we approach the film through an intersectional lens in order to demonstrate that the multicultural discourse offered by the film is part of a broader liberal project that elides structural inequity and instead seductively implies that race, gender, and sexuality are categories of identity which can be transcended through membership in the British nation. Our argument here is that in all cases, while the film appears on the surface to be progressive, it provides little in the way of a radical alternative. Third, and perhaps, counterintuitively given the preceding comments, our approach is also to emphasise the positive elements of the film. That is, we attempt to highlight the more salutary representational moments in the film as exemplars of the possibility the medium wields to expand the realm of social inclusion.

\section{Analytic Framework}

\subsection{Understanding Multiculturalism}

When we think of the word multiculturalism, we often imagine a society where different ethnicities seamlessly live alongside each other. For historically hegemonically white societies such as England and Canada that have been increasingly faced with immigration by nonwhite populations from around the world, multiculturalism has been understood to offer the perfect solution for how to create a more harmonious and integrated society (e.g., Kymlicka, 1995; Taylor, 1994). The discourse of multiculturalism suggests that racial inequality no longer exists in these societies, as each racial and ethnic group that forms a part of the multicultural mosaic is recognized for its unique value. On a broader scale-in the context of an increasingly cosmopolitan, globalized world, multicultural societies are valued for their diversity (Thobani, 2007). Thus, multiculturalism has come to challenge what it means to be Canadian or English. Yet, while this is an idyllic portrait of the contemporary multicultural society, much of the evidence states that things are not as they appear. In Canada, 
England, and Australia, multiculturalism remains a noble ideal more than a lived reality. There are three significant limitations with official multiculturalism (Bannerji, 2000) as practiced in places like Canada and England. First, as overwhelming evidence suggests, racial and economic inequality persists in multicultural societies. This is largely due to the fact that racial inequality stems from economic and political factors that are part of the capitalist and colonialist mode of production. In their book Racial Oppression in Canada, Peter $\mathrm{Li}$ and B. Singh Bolaria argue that "the oppression of racial groups is by no means a historical accident, but is rooted in the social and economic development of Canadian society" (1988, p. 14). Thus, in spite of the best intentions of some, racial inequality, as with all forms of social inequality, cannot be eliminated without significant attention to the economic and political roots of racism.

Second, instead of alleviating racial inequality, the policy of multiculturalism actually reinforces racial inequality and hierarchy. This is done in two ways. On one hand multiculturalism establishes and maintains the idea of an official "national" culture while relegating "other" cultures to a secondary or marginalized status. This "core" culture is what all must conform or assimilate to with very few exceptions (Coleman, 2006). Canadian cultural theorist Eva Mackey writes: "[A] problem with [multiculturalism], as many have pointed out, is that [it] implicitly constructs the idea of a core English-Canadian culture, and that other cultures become 'multicultural' in relation to that unmarked, yet dominant, Anglo-Canadian core culture" (2002, p. 2). So, in spite of claiming to be multicultural, such societies still retain the idea of a dominant culture. The core culture, as theorists like Mackey and Coleman, have pointed out, is whiteness. For example, many will still claim such a thing as real Canadian culture, which, as we have come to know, is symbolized by beer, hockey and Tim Horton's, while British culture is seen as the Union Jack, fish and chips and, once again, beer. Both, in the British and Canadian cases, are shorthand for whiteness.

On the other hand, multiculturalism also reinforces racial hierarchy by purporting to be the antidote to racial inequality. In fact, if one suggests that racial inequality or racism exists in Canada, for example, many are quick to deny those allegations and offer the policy of multiculturalism as proof of racism's absence. As a result of this, it is often difficult to make claims of racism within multicultural societies. Racial inequality is often swept under the rug and the dominant way of discussing ethnicity is via food, music, and costume, for these forms of difference are permitted by the hegemonic nation as long as they are accompanied by a willingness to submit to the society's structural norms (whiteness, capitalism, patriarchy, heteronormativity, etc.) (Ahmed, 2000). This can make it seem as if there are no inherent problems with multiculturalism. As such, whenever problems do arise, this way of looking at things prevents an honest and open examination of the issues. Rather, any problems involving non-white peoples are often blamed on their lack of ability to integrate and abide by the laws of the host society. For example, it is common in Canada and England to hear of the reluctance of non-white populations, be they Chinese, Muslim or any other group, to accept or assimilate to the norms and traditions of the host, or white, society. Commentators who support multiculturalism see any social problems within these societies as an example of "culture clash". This has the effect of continually denying racial inequality as the source of social problems. Multicultural theorist Amita Handa (2003) suggests that while culture clash seems like a plausible explanation for social problems, each culture carries a certain "weight" as it were. In other words, cultures are not equally weighted. As she puts it, Canadian, or "core culture" has "the (relative) social, economic, and political power and representational resources to enforce itself" (p. 5).

The third limitation of multiculturalism is that its idea of culture is very narrow and relies on a number of stereotypes. This is another way of saying that multiculturalism essentializes culture. Culture within multiculturalism is often reduced to food, clothing, dance, and music. When we are asked about Greek culture, many of us know souvlaki and ouzo but are hard pressed to name any Greek poets or the current Greek president. The same is true for Indian culture: we often know it as sweets, saris, and tandoori chicken but we know very little about India beyond this oversimplification. As such, instead of culture, something that is politically, historically, and economically informed, multiculturalism presents a series of caricatures that may seem cute, but do not tell the whole story of a culture or society. More importantly, these multicultural versions of culture are frozen in time. That is, they do not testify to the ways in which all cultures are constantly in flux since culture is historically-constituted rather than natural. Thus, multiculturalism narrows the cultural field and limits the ways in which people from "other" communities can speak. If they don't speak the language of food, music and costume, many are quick to ignore them (Mackey, 2002).

The connection between racial inequality and multiculturalism should become clearer if we look at the economic and political trends that have produced multicultural societies. Contrary to what some might think, policies of multiculturalism were not founded on benevolence. Rather, metropolitan countries such as Canada and England have used immigration in order to meet their labour needs (Sharma, 2006). Thus, the policy of official multiculturalism in Canada is economic and political in origin. According to Himani Bannerji (2000), Canadian multiculturalism actually emerged as 
a way to manage the problem of an increasingly disenfranchised population who were asking for increased civil and political rights. Moreover, it was also enacted to dampen the fire of the Quebec separatist movement. Thus, on this level, official multiculturalism was a selfinterested national/capitalist project to maintain privilege by the dominant group in society (Handa, 2003, p. 3).

\subsection{Film, Sport and Multiculturalism}

The significance of representation in this process cannot be overstated (Abdel-Shehid \& Kalman-Lamb, 2011). Images of multiculturalism in popular culture play a significant role in valorizing and legitimizing official multiculturalism. Films and stories of multicultural concordance in popular culture create the illusion that harmony and opportunity are pervasive at a historical moment in which marginalized people-particularly those with fewer economic resources-have increasingly limited opportunities due to neo-liberal policies that prevent the redistribution of wealth and the leveling of the economic playing field.

Moreover, our research shows that mainstream films, especially films about sport, have a relatively coherent structure. As we have argued, this structure's key component is the idea of transcendence. As we wrote (Abdel-Shehid \& Kalman-Lamb, 2011, p. 111):

There is one dominant feature that links both commercial film and high-performance sport. This feature is the idea of winning or transcendence. Transcendence is a term that refers to going beyond or surpassing all worldly constraints....Most of the films about sport...hold the idea of transcendence as the "carrot" in front of the viewer.

In fact, the notion of transcendence has been particularly prevalent in sports films dealing directly with the issues of "race" and racism, particularly in the context of the United States. Whether it is narrative films such as Remember the Titans and Glory Road-works of historical fiction-or documentaries such as Hoop Dreams and Through the Fire, the dominant themes, particularly in such U.S. films, have been that sports provide a mechanism to produce greater racial harmony (by bringing white and black players together) and also to offer impoverished black athletes an avenue to transcend into a higher social class. This is a deeply ideological and obfuscatory gloss on structural racism given that racism is, as Fanon (2004) puts it, "a compartmentalized world, a world divided". Hollywood film attempts to spin race in precisely the opposite way, suggesting instead that sport offers African-Americans a way to move out of this "compartmentalized world" in order to seek a better non-compartmentalised future. Ultimately, it is critical to examine the representational impact of films such as Bend it Like Beckham because they oversimplify the efficacy of sport as a site of social inclusion. Sport is simply one social site among many in a given society. If a society is rife with structural inequality, so too will be the sport of that society. Films about sport too often mislead viewers to believe that sport can offer a panacea to these much larger and more complex problems, in the process inducing political complacence. If we are serious about producing genuine social inclusion, we must begin by deconstructing the myth that it has already been achieved.

\subsection{Gender in Sport}

In addition, our theoretical framework reads gender in sport unlike the bulk of the literature, which tends to universalize the experience of women and girls (as well as men) in sport (Abdel-Shehid \& Kalman-Lamb, 2011). We specifically see gender as an historical category within the sphere of socio-economic relations of production. These specific relations of production include capitalism and neo-colonialism in the current context, but also slavery and colonialism in the past. These events force us to read gender, and all forms of social identity, not as existing alone, but rather as existing in relation to one another, and therefore as being determined not solely by patriarchy (Abdel-Shehid, 2005; Abdel-Shehid \& Kalman-Lamb, 2011).

\section{Research Method}

The paper takes the position that cultural studies, in addition to being a theoretical approach, is also a research method. In this sense, our approach to cultural studies borrows from the work of Stuart Hall (1997). Hall argues that the meanings viewers glean from cultural productions are not arbitrary. On the contrary, meaning is anchored by context. When a particular image is persistently coded and disseminated in a specific way in a given a society, that becomes the dominant way of reading the image in question. So, for example, when black men are consistently depicted as criminal, blackness becomes associated with criminality. At a certain point, the image of a black man does not need to be engaged in a criminal act in order to evoke criminality, for this context already exists in the mind of the viewer. Following Hall, we argue that the depiction of multiculturalism and gender in Bend it Like Beckham is understood by viewers through the broader prism of multicultural discourse and notions of masculinity and femininity. In a sense, the film is a reassertion of lessons that viewers have already been taught in various ways. This provides the film with tremendous power, for instead of appearing to be one unique perspective on the experience of young women playing football in Britain, it instead reads as a statement of fact about the nature of the world. 


\section{Film Analysis}

It is with all this in mind that we will examine Gurinder Chadha's 2002 motion picture Bend it Like Beckham. This film, which was successful in India, as well as in England, Australia, and North America, is an interesting example of popular culture's role in shaping ideas about multiculturalism and gender. On first glance, the film is enjoyable. It contains excellent performances, especially by Anupam Kher (Mr. Bhamra), Parminder Nagra (Jesminder Bhamra) and Keira Knightly (Jules Paxton). In addition, the film has a very nice, lively soundtrack and a wonderfully happy ending. Third, if one has any interest in food, sport, or music, it is hard not to like the film. Like many Bollywood films, it is a feast for the eyes. There are several tantalizing shots of nice Punjabi dishes and, if one has an eye for these things, very athletic young women demonstrating their prowess and having great fun in doing so. Fourth, what makes the film compelling is its subject matter. The issue of second-generation immigrant middle class kids wondering how to negotiate between their family's demands and those of the outside society is a concern for increasingly large portions of the population in places such as England and Canada. While this issue is growing, it receives little attention in popular culture. With all of this, one can ask the question: what's not to like about the film? This is indeed a fair question. What follows is an attempt to look at what the film is saying beneath the music, tasty-looking dishes, and scenes of athletic excellence. Specifically, we will look at the film keeping in mind the critiques of multiculturalism discussed above and ask the question: what message about culture and gender, and by extension, social inclusion, does Bend it Like Beckham put forward?

The film is the story of two eighteen year old athletes: Jesminder "Jess" Bhamra and Jules Paxton. Jess comes from a Sikh family living in London. She is an avid footballer, although her exploits are limited to recreational triumphs over her male friends in the park. Early in the film she is discovered by Jules, an AngloSaxon Briton from a middle class family who plays for a local women's team called the Hounslow Harriers. The film traces the struggles of both girls to find acceptance as athletes. Jess must overcome the resistance of her family, particularly her mother, who feel both that sports are not an appropriate activity for girls and that Jess should focus her attention on becoming a lawyer. Jules' challenge is to confront her mother's associations of athleticism with masculinity and homosexuality. Ultimately, these conflicts are reconciled, as both young women accept athletic scholarships to attend university in the United States.

Unlike many Hollywood films about sport, Bend it Like Beckham seems conscious of its potential social and political impact. The predominant issues dealt with in the film-multiculturalism, gender, and sexuality- each explicitly engages with a form of injustice and offers relatively progressive solutions. Among the film's primary mandates is an attempt to articulate a sophisticated version of multiculturalism that allows for hybrid or blended identities. While there has been significant academic writing on the question of hybridity within multicultural societies, we are not referring to Homi Bhabha's (2004) use of the term, as outlined in the various essays of The Location of Culture. Instead, we are indexing something more in line with what $\mathrm{Hi}-$ mani Bannerji (2000) calls popular multiculturalism, which refers to the everyday ways that cultures are made anew amidst difference. In other words, its ambition is to show us that the categories "Asian" and "English" are not mutually exclusive. Rather, it seeks to show that Englishness has become a multicultural concept open to people of diverse backgrounds, each of whom in turn comes to inform what it means to be English. Thus, in the film, we see myriad examples of flourishing multiculturalism, from the diverse constitution of the Harriers to Jess' ability to move comfortably at the end of the film from her sister's Indian wedding to a Harriers match and then back again.

Nearly as significant thematically is the film's focus on gender. Historically, sporting activities have generally been considered aspects of masculinity, diametrically opposed to feminine attributes. Bend it Like Beckham refuses to accept this understanding. On the contrary, it suggests that women are perfectly capable of competing in sport and that this is an entirely appropriate activity for them to be engaging in. Consequently, throughout the film, viewers are provided with shots of the Harriers playing impressive football. Likewise, they are also shown defying instances of misogyny. Early in the film, three of the South Asian boys Jess is playing with in the park begin making fun of her after she is fouled. One of them asks, "Who does she think she is, Beckham or what?" Another pointedly says to Jess in a sexually suggestive manner while jiggling his chest, "Can you chest it like him? You know, give us some bounce". The third adds, "Chest it Jess, go on". Although these are clearly attempts to reduce Jess to a sexual object, thus negating her performance, she is unperturbed. Instead, she slams the ball in the third player's groin area, suddenly turning him into the object of scorn. Soon after, back in her room at home after she has left the park early to help with chores, she foregrounds gender inequity by saying, "It's not fair, the boys never have to come home to help".

Finally, issues of sexuality are also tackled in a progressive manner in the film. Since the mid $20^{\text {th }}$ century, women involved in sport have often been labeled lesbians. Such claims have not been merely descriptive. Rather, in the homophobic contexts in which they have been delivered, accusations of homosexuality have worked to discourage women from entering public spheres previously reserved for men (Cahn, 1994; Ab- 
del-Shehid \& Kalman-Lamb, 2011). Bend it Like Beckham rightfully challenges homophobia. The most homophobic character in the movie, Jules' mother, is also the most ridiculous. Early in the film, Mrs. Paxton worries that Jules is not feminine enough to attract a boyfriend because of her preoccupation with football. However, midway through the film she overhears an argument between Jules and Jess over their coach Joe. Mrs. Paxton thinks that she has heard her daughter tell Jess that she has broken her heart, when in fact it is Joe that Jules is talking about. This misunderstanding leads Mrs. Paxton to think that her daughter is a lesbian, something she is clearly not comfortable with as she first weeps and then later confronts the girls about it at Jess' sister's wedding. Although this homophobia might appear problematic, its impact is minimized by the fact that it is Jules, not her mother, who has credibility in this film. Jules may be athletic, but she is not a lesbian. Moreover, at the end of the film, after proving to her mother that she is not gay, Jules tells her, "Anyway, being a lesbian is not that big a deal", (cited in Giardina, 2006, p. 49).

Nevertheless, while the film demonstrates some awareness of social inequality, it is clear on closer examination that this critique remains moderate and relatively superficial. Director Chadha does not tell viewers that assimilative nationalism or male dominance in sport are fundamentally problematic; on the contrary, she asks viewers to "bend" these systems in order to create more opportunities for non-white people and women. Thus, by accepting these structures as they are rather than offering alternatives, Chadha reproduces many of their problems.

Although Bend it Like Beckham may seem to advocate a more fully-realized form of multiculturalism, one in which individuals can identify as both English and Asian, this progressive vision is undermined and even contradicted by several aspects of the film. In fact, the film reproduces two of the limitations of multiculturalism discussed above. First, we can say that the overall message of the film is actually one of assimilation to a "core culture", which in this case is the white, English norm. Assimilation is what saves Jess Bhamra. Moreover, Jess' sister, Pinky, who agrees with her parents' vision of womanhood, is not taken seriously in the film and dismissed as a fool. The binary between Jess and her sister is one of the main ways the plot of the film is advanced. Jess is represented as modern and therefore serious, while Pinky is represented as traditional and foolish. While we are not advocating either position, we are left asking what the film would have looked like if both sisters were represented in as multidimensional a way as Jess is.

The other area where the film reproduces the limitations of multiculturalism is in its depiction of "Indian culture". The film reduces Indian culture to food, music, and marriage. None of the complexities of Indian culture, or any other culture for that matter, are shown in the film. It is as though the only thing preoccupying South Asians in England is food and wedding plans. While this is true for some, it is certainly not true for all, and the film runs the risk of reproducing stereotypes by not offering a more complex portrait of Indian culture in England. The character of Mrs. Bhamra, Jess' mother, is perhaps the most disturbing in the film. She is represented without any complexity and all of her aspirations come down to food, marriage, and modesty. This is a mythical representation in line with the work of semiotician Roland Barthes. For Barthes, myth is one of the primary ways that bourgeois society reproduces itself. Myth, according to Barthes, is an evacuation of history $(1972$, p. 118). What he means by this is that ideas and images in capitalist society are depicted in a manner that is divorced from their historical context so that they come to appear natural and timeless. This is a powerful ideological tool, for it forecloses possibilities for resistance against the status quo by suggesting that no other ways of organizing society exist as alternatives. In the language of Barthes, then, Mrs. Bhamra and her family are presented in a mythical fashion precisely because their portrayal presents a conflict between Asian traditionalism and English modernity without providing any of the context around colonialism that might render it comprehensible as a historical contingency. Divorced of this context, Mrs. Bhamra comes to stand in for an essential conservative Indian culture that obstructs Jess from attaining the bountiful opportunities proffered by an essentially progressive English society. For example, early on in the film, Mrs. Bhamra is asked if she is proud of her daughter's football successes. She responds: "Not at all! She shouldn't be running around with all these men, showing her bare legs to 70,000 people." In addition, consider the following scene. When Mrs. Bhamra finds out that Jess wants to play for the Harriers, she informs her that she cannot since there are, significantly, Asian activities she must perform instead:

You've played enough...l don't want you running around half-naked in front of men... What family will want a daughter-in-law who can run around kicking a football all day but can't make round chapattis? Now exams are over, I want you to learn full Punjabi dinner, meat and vegetarian...That's it: no more football.

In yet another scene, we see Mrs. Bhamra stir food in a pan while Jess plays keep-ups with a cauliflower. However, as soon as Mrs. Bhamra sees what her daughter is up to, she grabs her arm and drags her to the frying pan. Likewise, towards the end of the film, at a party the night before her sister's wedding, Jess kicks a football around while wearing a sari. Again, Mrs. Bhamra is there to squash the moment, giving Jess a platter of 
food to circulate. Essentially, each time Jess attempts to express her impulses towards this English activity she is impeded by alternative Asian cultural practices, often embodied in the figure of her mother. This has the effect of reducing Indian culture and makes it seem that the only logical choice for Jess would be to adopt the English lifestyle. Englishness is thus portrayed as inherently modern and progressive, while Asianness is reduced to a conservative traditionalism, a classic Orientalist trope (Said, 1979). Importantly, it is left to Jess' white coach Joe (played by Jonathan Rhys Meyers) to rescue her from her tradition-bound family by pleading that she be allowed to play football. This too is a colonialist narrative, as the British persistently positioned themselves as defenders of Indian women against the ostensible tyranny of Indian culture (Mani, 1998). Thus, while we might acknowledge that many middle-class immigrant kids and youth are put in the difficult position of having to negotiate a somewhat divergent cultural terrain, in order to demystify the mythical depiction of the Bhamra family, it is necessary to understand that historically English culture was instrumental in the production of racial inequality and also that English society today is far from as welcoming of non-white people. This is context the film does not sufficiently provide.

In that sense, the film reinforces a third limitation of multiculturalism, which is that it is often seen to be an antidote for racial inequality. The film advances the position taken by culture clash theorists that if there are any difficulties for immigrants to integrate into a host society, the fault lies with the immigrants' rigidity, and not with the racial inequality or racism that is part of the host culture's view of "outsiders". For example, throughout the film, while Jess' Asian heritage is consistently portrayed as an impediment to multiculturalism, it is her English friends who are repeatedly seen as welcoming her. This is most apparent in her relationship with Jules. To begin with, the stereotypically Anglo-Saxon Jules is the one who invites Jess to play with the Harriers. Moreover, whenever Jess comes over to Jules' house, she is made to feel welcome. Mrs. Paxton offers her traditional English snacks and asks her questions about her Asian culture, going so far as to implore Jess to teach some of her culture's values to Jules. Jess' interactions with the Paxtons make it clear that the English welcome multiculturalism even as her own Asian family rejects it.

The primacy of English identity over Asian identity is further reinforced near the end of the film. During the climactic football match at the end of the film, which Jess has left her sister's wedding to attend, we see Jess become fully English by overcoming her Asian past, not by merging the two into a hybrid future. Giardina neatly describes this scene. After Jess is fouled, she gets up to take the free kick:

As the wall forms in front of her, blocking the goal, time slows and "Nessum Dorma", the tenor aria from Puccini's Turandot, plays in the background. Instead of seeing a wall of opposing players, she sees her sister, mother, grandmother, and auntsall dressed in their wedding attire-blocking (her) goal (Giardina, 2006, p. 48)

Jess bends the ball around her family and into the net. The message of this scene is powerful and unambiguous. Jess has finally triumphed over her Indian background to become genuinely English. It is not an accident that her family is figured in this sporting context as her opponents. There is particular symbolic significance here. The film quite clearly states that ethnic fusion, or genuine multiculturalism, is not the ideal. There can be no ethnic fusion - it must be England versus Asia and England must prevail.

At the end of the film, Jess finally chooses to accept the scholarship that she has been offered to play football in the United States and must break the news to her family. When she does, she echoes Joe's words of wisdom from earlier in the film: "And if I can't tell you what I want now, then I'll never be happy, whatever I do". By articulating the decision to reject her family's aspirations in precisely the words used by her assimilated English coach, Jess reveals once all for all that she has been subsumed by her new English identity. She has chosen England over India, not found a way to live both identities at the same time.

Progressive multiculturalism is not the only social theme Bend it Like Beckham pursues. Equally significant is its vision of women's empowerment. Yet, just as assimilationist ideas are embedded within the multiculturalism of the film, so too are traditional gender roles reasserted even as others are overcome. At first glance, it is hard to deny the positive messages of the film with respect to gender. With the exception of Mrs. Bhamra and her daughter Pinky, the film portrays strong, resilient, proactive women who enter a sphere formerly reserved for men and thrive in it. This, in and of itself, is doubtless positive in its implications for viewers of the film. However, without probing further into the construction of gender in the film, we risk swallowing some considerably more troubling notions about sex and gender, namely suggestions of the validity of feminine chastity, masculinity, and patriarchy along with the good.

Generally, traditional norms of femininity-the requirements to be physically appealing to the male gaze, heterosexual, and domestic, to name a few-are rejected in the film. But sadly, this is not done in a complex way. Rather, as previously mentioned, the characters that conform most closely to what we could call "traditional femininity" are seen to be the least credible. Consider the following examples. At the end of the film, Pinky says of her wedding to Jess, "Don't you want all this? This is the best day of your life, innit?" 
Jess responds: "I want more than this". Similarly, the mothers of both Jess and Jules live their lives according to conventional feminine roles. Mrs. Bhamra spends most of her time in the kitchen preparing food for her family. Mrs. Paxton takes her daughter bra shopping and is interested in which boys Jules prefers, not how many goals she scores. The attempts of both these maternal figures to feminize their daughters are greeted with little success. Jess plays football in the kitchen, while Jules selects a sports bra rather than the push-up bras advocated by her mother. What is troubling about this pattern is that those women choosing an alternative to the typical North American form of femininity, symbolised by independence, cutting of family ties, and no interest in cooking, are seen in a very narrow fashion. Because they are seen in such a comical light, we are not offered a window into why these women made these choices. They are merely seen as backward and foolish.

While the more exaggerated forms of femininity are dismissed in the film, it does not mean that Bend it Like Beckham abandons all traditional ideas about femininity. In fact, the film's rejection of "traditional" femininity enables it to retain ideas about femininity all the same. Consider the following examples. While playing football in the park early in the film, Jess is called over by three Asian girls who have been admiring the physiques of the boys Jess is playing with. When they tease Jess about her relationship with her friend Tony, Jess responds: "Oh, shut up. You know he's just my mate. We're not all sluts like you lot". Coming as it does from the clearly sympathetic protagonist of the film, this epithet serves to reassert for the audience the equation between femininity and chastity. Apparently, although women may seize control of their bodies for sport in Bend it Like Beckham, the same does not go for sexuality. Later, in Germany, the team plans to go out for a night on the town after their games. Jess, clearly uncomfortable, realizes that she has not brought "appropriate" clothes. Jules calls in Mel, and when we next see Jess she is heavily made up and wearing a tightfitting dress. From the admiring looks she gets from her teammates and Joe, it is evident that we are supposed to appreciate the transformation. The implication here seems to be that progressive women must be footballers and beauty queens. This provides little space for girls and women who would prefer not to accept traditional norms of feminine beauty. The fact that all of the girls on the team would make themselves up for a night out tells us that this is still an expected part of feminine behaviour. Soon after, as Jess is about to kiss Joe in Hamburg, Jules sees them and calls her friend a "bitch". The use of this misogynistic word by one of the female protagonists of the film cannot help but legitimize it. For young audiences of the film (Bend it Like Beckham can often be found in the children's section at video stores) this may become an epithet of choice in similar situations, in the process reproducing its harmful connotations. Thus, although Bend it Like Beckham dismisses stereotypical forms of femininity, and opens up new spaces for women-notably on the football pitch - it continues to carefully draw the lines of femininity outside the football pitch.

Moreover, the gender norms associated with football in the film are consistently tied in to ideas about masculinity-courage, toughness, and aggressiveness, even as the games are played by young women. In fact, it is all too apparent that according to the film, for a girl to play soccer legitimately, she must play like a man. When Jules first tries to sell Joe on the possibility of Jess as an aspirant for the Harriers, she tells him, "She's got balls Joe, at least watch her". The more she plays like a man, the more viable a candidate she is for the team. Later, Jess again proves her toughness after she has been punished in practice by Joe, who forces her to run laps: she runs until she injures her leg, refusing his injunctions to stop. When Jules asks her if Joe was too hard on her and tells her that some of the girls find him to be too strict, Jess demurs, suggesting that he behaved in an appropriate manner: "No, he was really nice, just really professional". In this way, the critique of aggressive masculinity in sport and authoritarian coaching leveled by the other girls is dismissed as illegitimate. Finally, during a game later in the season, we see one of the Harriers players wipe blood off of her knee and return to the game. Again, this is a reassertion of the masculine sporting ethic: stoicism is prized and pain is disdained. The potential repercussions of such images are significant. Although the film tells viewers that women can and should play, it also tells them how they should play-like a "man". This forecloses the possibility for alternative approaches to sport, for instance as a site of pleasure and companionship as opposed to combative competition.

Perhaps the most blatantly problematic gender portrayal in the film comes from the pervasiveness of what Giardina calls "the all-discerning male voice of reason" (2006, p. 47). That is, throughout the film, male characters are figured as wise, compassionate, and authoritative patriarchs, in contrast to their female counterparts. In Jess' family, this distinction is apparent immediately from the start of the film. Jess is watching a football match featuring Beckham when her mother rudely interrupts her. The mother bursts into her room yelling and demands that she stop watching. Jess is left seething. However, soon after, her father enters her room and kindly convinces her to come downstairs. The key difference is that he is able to understand the significance of the game to his daughter in a way that his wife does not. Since the significance of football to Jess is apparent to viewers of the film, Mr. Bhamra immediately comes off in a compassionate and sympathetic light. Jules' father is presented in much the same way. In a scene early in the film, Jules and her father play football together in the garden. Mrs. Paxton inter- 
venes and chastises her daughter for not being feminine enough, prompting Jules to storm out of the yard. Mr. Paxton tells his wife, "See what you've done? Why don't you just get off her flaming back? If she's more interested in playing football right now than chasing boys, then quite frankly I'm over the moon about that". This is both a reassertion of the importance of feminine chastity and a demonstration of paternal wisdom. Like Mr. Bhamra, he is able to understand the importance of football to his daughter and to recognize the absurdity of gender conventions discouraging women's participation in sport. Even Joe, although younger, is established as a figure of masculine wisdom and authority. Although it is Jules who scouts Jess and suspects that she would be a good fit for the team, she still requires Joe's ultimate affirmation to confirm her own opinion.

In the climactic scene at the end of the film, in which Jess tells her family that she wishes to pursue the scholarship she has been offered in the United States, we are provided with an ultimate display of patriarchal wisdom and authority. Upon hearing the news, Mrs. Bhamra is enraged and immediately rejects her daughter's decision. Mr. Bhamra, on the other hand, gathers himself to think about what she has said, strolling away from the living room where the family is gathered into the kitchen. When he returns, he has made up his mind. He tells the family of his own decision to give up cricket and compares that to Jess' situation. He resolves that she should not make the same mistake that he did and authorizes her to go. This moment is significant on a couple of levels. First, the film in no way undercuts his masculine authority to be the final arbiter on the subject. Second, his rational wisdom and compassion contrast directly to the impulsively irrational response of Mrs. Bhamra. It is clear throughout the film that when difficult decisions must be made, they must be made by a man. This message, like the reassertions of feminine gender norms off the pitch and masculine norms on it, serves to undermine the progressive messages of the film.

\section{Conclusion}

Ultimately, due to its reassertion of traditional norms such as assimilation, femininity, and patriarchy, we find the film Bend it Like Beckham to be limited in its potential as a political intervention against whiteness and traditional gender norms. While it may be entertaining, it is clear the film offers few choices for immigrant families trying to negotiate the terrain of culture or young women chafing under feminine conventions. In this regard, we can say that the film cements the culture clash argument, thus reinforcing the message that assimilation is the only way forward for multicultural societies.

However, perhaps we need not end on the most pessimistic note. Limitations aside, perhaps one posi- tive aspect of the film is in its critique of those who cling to the cultural past. This is the film's strongest message, although unfortunately it came in the form of a caricature of Mrs. Bhamra and Jess' sister Pinky. Yet this criticism is indeed relevant, and it is worth discussing in detail. To this end, we refer to an essay by the novelist Salman Rushdie entitled "Imaginary Homelands" (1991). In the essay, Rushdie discusses the process of migration, or what it means to move from one country to another. For anyone who has migrated transnationally, or knows someone who has, it is indeed a very difficult and trying experience. The process involves a great deal of loss. Often, one leaves behind friends, family, furniture, food, and music in the transition. Rushdie notes that this process has a profound effect on the psyche, which often does all it can to piece things together as they were before. In the face of new and often unfriendly surroundings, the migrant sometimes uses her memory to make the most sense of the new world confronting her. In that sense, when one leaves a place, the only thing one can truly count on is memory, since all else is incomplete. When this occurs, the temptation is to try and rebuild the old country in the new. But Rushdie notes that even memory is never complete; in other words, never something that can be fully relied upon. He notes $(1991$, p. 10) that "exiles or emigrants or expatriates are haunted by some sense of loss, some urge to reclaim, to look back". Yet, he cautions those who do look back to recognize that they can never fully replace the past. He continues by saying that invariably, the memory creates "fictions, not actual cities or villages, but invisible ones, imaginary homelands, Indias of the mind".

This is an important message. The character of Mrs. Bhamra in the film represents the problem with trying to fully reproduce the lost culture. This may explain the insistence on learning to get the dishes right and doing things exactly as they were back home. By desperately trying to recreate an "imaginary homeland" in England, and trying to force everyone around her to do the same, Mrs. Bhamra ends up losing even more. Rushdie, who spent years in hiding from Islamic fundamentalists after the publication of his novel Satanic Verses, is warning against the common tendency to fix culture and identity. Rushdie was not alone in this opinion. His feelings were part of a wave of writing in the 1980s and 1990s specifically in Britain that took this position. It is clear that a younger Chadha was part of this wave, if one looks at her earlier works, such as Bhaji on the Beach. In his essay, then, Rushdie closes with a plea for more fluidity when we perceive culture and asks us to "open the universe a little more". On the surface, Chadha wants to do the same, but instead, she ends up missing the mark and reinforcing the idea of a "core culture". This is because she only sees the Indian culture as static and not the dominant culture. As such, we are left asking: is assimilation the same thing as 
opening the universe? Moreover, the film is weakened by the fact that the static Indian culture is not explained sociologically. Instead, the film reproduces the idea of what Fanon (1988) referred to as racism's tendency to create a "fossilized" culture. Yet, it pays no attention to the way in which it is in fact racism that tends to fossilize culture, in spite of claims that multicultural society is open to change. Thus, in light of Fanon's claims, we can read Chadha's representation of Indian culture, specifically in the form of Mrs. Bhamra and Pinky, not as true per se, but rather as the outcome of a racist hegemonic culture that does not allow other cultures to flourish and to grow. In addition to Rushdie's plea to open the universe, we could also borrow from the conclusion of Fanon's essay "Racism and Culture": "The characteristic of a culture is to be open, permeated by spontaneous, generous, fertile lines of force" (1988, p. 34). For Fanon, "lines of force" refer to a cultural engine; those things that make culture change, that move it from being on "object" to something more dynamic. It is this spirit of openness, perhaps, which is Chadha's strongest, if occluded, message.

What is clear here is that in the context of sport and social inclusion, the film Bend it Like Beckham should be read metonymically. In other words, the film should be read as a text about a society that has a significant social impact. If we treat the film as such, we are offered a glimpse as to the challenges that sport holds for social inclusion. The primary research finding of this paper is that if sport participation for young women from ethnic groups outside the core culture leads to an assimilationist perspective, we end up leaving the problem of racism alone, in spite of the success that some athletes have. One further implication, especially from the point of view of sport policy researchers, is to interview young female athletes outside the core culture, to see the extent to which assimilation is part of their success in high-performance sport. It seems that this may be the case, but further research is necessary to solidify these findings.

\section{Conflict of Interests}

The authors declare no conflict of interests.

\section{References}

Abdel-Shehid, G. (2005). Who da' man? Black masculinities and sporting cultures. Toronto: Canadian Scholars Press.

Abdel-Shehid, G., \& Kalman-Lamb, N. (2011). Out of left field: Critical perspectives on social inequality and sports. Winnipeg: Fernwood Press.

Ahmed, S. (2000). Strange encounters: Embodied others in post-coloniality. New York: Routledge.
Ahmed, S. (2010). The promise of happiness. Durham: Duke University Press.

Bannerji, H. (2000). The dark side of the nation: Essays on multiculturalism, nationalism and gender. Toronto: Canadian Scholar's Press and Women's Press.

Barthes, R. (1972). Mythologies. New York: Hill and Wang.

Bhabha, H. (2004). The location of culture. London: Routledge.

Bolaria, B. S. \& Li, P. S. (1988). Racial oppression in Canada. Toronto: Garamond Press.

Cahn, S. (1994). Coming on strong: Gender and sexuality in twentieth-century women's sport. New York: Free Press.

Coleman, D. (2006). White civility: The literary project of English Canada. Toronto: University of Toronto Press.

Fanon, F. (1988). Towards an African revolution. New York: Grove Press.

Fanon. F. (2004). The wretched of the Earth. New York: Grove Press.

Giardina, M. D. (2006). "Bending it like Beckham" in the global popular: Stylish hybridity, performativity, and the politics of representation. In C. R. King \& D. J. Leonard (Eds.), Visual economies of/in motion: Sport and film (pp. 33-56). New York: Peter Lang Publishing.

Hall, S. (1997). The work of representation. In S. Hall (Ed.), Representation: Cultural representations and signifying practices (pp. 13-74). London: Sage.

Handa, A. (2003). Of silk saris and mini-skirts: South Asian girls walk the tightrope of culture. Toronto: Women's Press.

Kymlicka, W. (1995). Multicultural citizenship: A liberal theory of minority rights. Oxford: Oxford University Press.

Mackey, E. (2002). The house of difference: Cultural politics and national identity in Canada. Toronto: University of Toronto Press.

Mani, L. (1998). Contentious traditions: The debate on sati in colonial India. Berkeley: University of California Press.

Rushdie, S. (1991). Imaginary homelands: Essays and criticism, 1981-1991. London: Granta Books.

Said, E. (1979). Orientalism. New York: Vintage.

Sharma, N. (2006). Home economics: Nationalism and the making of "migrant workers" in Canada. Toronto: University of Toronto Press.

Taylor, C. (1994). The politics of recognition. In A. Gutmann (Ed.), Multiculturalism: Examining the politics of recognition (pp. 25-73). Princeton: Princeton University Press.

Thobani, S. (2007). Exalted subjects: Studies in the making of race and nation in Canada. Toronto: University of Toronto Press. 


\section{About the Authors}

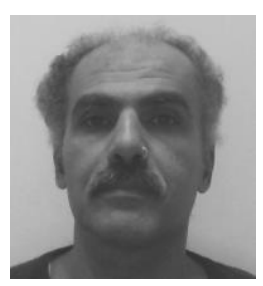

\section{Dr. Gamal Abdel-Shehid}

Gamal Abdel-Shehid is Associate Professor in the School of Kinesiology and Health Science at York University. He is the author of Who Da Man: Black Masculinities and Sporting Cultures (2005) and coauthor of Out of Left Field: Social Inequality and Sports (2011).

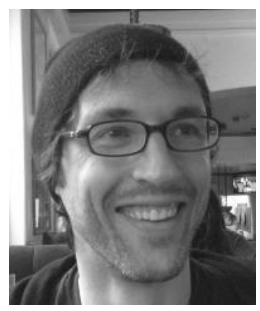

\section{Nathan Kalman-Lamb}

Nathan Kalman-Lamb is a Ph.D candidate in Social and Political Thought at York University. He is the co-author of Out of Left Field: Social Inequality and Sports (2011). 